\section{Occupational Asthma Caused by Actinia equina}

Subiza $\mathrm{J}^{1}$, Kilimajer $\mathrm{J}^{1}$, Barjau $\mathrm{C}^{1}$, Bravo $\mathrm{F}^{2}$, Cases $\mathrm{B}^{3}$, Fernández Caldas $\mathrm{E}^{3,4}$

${ }^{I}$ Subiza Centre of Allergy and Clinical Immunology, Madrid, Spain ${ }^{2}$ Asepeyo, Madrid, Spain

${ }^{3}$ Inmunotek, Madrid, Spain

${ }^{4}$ University of South Florida College of Medicine, Tampa, Florida, USA

J Investig Allergol Clin Immunol 2018; Vol. 28(4): 277-278 doi: 10.18176/jiaci.0262

Key words: Actinia allergy. Mussel anemone allergy. Occupational asthma. Palabras clave: Alergia a la actinia. Alergia a la anémona del mejillón. Asma ocupacional.

The term anaphylaxis was coined by Charles Richet and Paul Portier when they tried to immunize dogs with Actinia extracts in 1902 [1]. Very few cases of IgE-mediated allergy caused by Actinia have been reported. We report on 2 patients with occupational asthma caused by the beadlet anemone Actinia equina.

The first patient was a nonsmoking fisherman who loaded and unloaded mussels at a mussel farm. He had a 10-year history of episodes of pruritus, hives on exposed areas of skin, sneezing, oculonasal itching, cough, and wheezing with dyspnea.

These symptoms only occurred when he was working on the boat, especially when loading and unloading mussels. His symptoms improved with $\beta$-agonist inhalers as needed, and he was symptom-free when not working, during the weekends, and on holiday.

The patient clearly relates his symptoms to exposure to the beadlet anemones on the mussel shells.

The second patient was a nonsmoking 58-year-old woman who had worked for 40 years at a mussel treatment plant. In November 2015, she began to experience episodes of sneezing, oculonasal itching, cough, wheezing with dyspnea, and nocturnal dyspnea. She attended the emergency department on 5 occasions, despite having been treated with regular high doses of budesonide and formoterol.

Her symptoms improved during the weekends and worsened during working hours. She reported that the anemones on the mussel shells triggered her symptoms.

Neither patient was taking medication when they came to our allergy center. The results of the physical examination and pulmonary function tests were normal. Bronchodilation tests were positive in both patients. Biochemistry and blood counts were normal, except for slight eosinophilia in patient 2 . Total IgE was $175 \mathrm{kU} / \mathrm{L}$ and $285 \mathrm{kU} / \mathrm{L}$ in patients 1 and 2, respectively. Chest $\mathrm{x}$-rays were normal in both cases.

The methacholine challenge showed bronchial hyperresponsiveness in patient 1 (methacholine $\mathrm{PC}_{20}, 0.8 \mathrm{mg} / \mathrm{mL}$ ) and in patient 2 (methacholine $\mathrm{PC}_{20}, 1.6 \mathrm{mg} / \mathrm{mL}$ ).
The $A$ equina extract was prepared from anemones on the mussel shells, which were brought to Madrid by the patients themselves from their work places. These were transported and kept in seawater. Marine biologists from the Consejo Superior de Investigaciones Científicas (Spanish National Research Council) in Madrid identified the species of the anemones.

A equina were carefully removed from the mussel shells before being liquefied (1:1 wt/vol). The anemone extracts were filtered through a filter paper (Whatman Ltd.) and sterilized using a $0.22-\mu \mathrm{m}$ membrane (Millipore), with a final protein concentration of $687 \mu \mathrm{g} / \mathrm{mL}$, as determined by the Bio Rad protein assay [2].

Skin prick tests using this anemone extract were positive in both patients, as follows:

Patient 1: A equina, $9 \mathrm{~mm}(3+)$; histamine $(10 \mathrm{mg} / \mathrm{mL})$, $6 \mathrm{~mm}$; glycerol saline, $0 \mathrm{~mm}$. End point titration was at 1:100 $000 \mathrm{wt} / \mathrm{vol}$.

Patient 2: A equina, $7 \mathrm{~mm}(2+)$; histamine $(10 \mathrm{mg} / \mathrm{mL})$, $8 \mathrm{~mm}$; glycerol saline, $0 \mathrm{~mm}$. End point titration was at $1: 10000 \mathrm{wt} / \mathrm{vol}$.

The tests with the extracts were negative in 5 nonatopic controls.

Skin prick tests using a battery of common inhalants and food extracts, including mussel and seafood, were negative in both patients.

A bronchial provocation test with extract was performed in both patients following the technique previously described by our group [3]. On the day of the test, no significant variation in $\mathrm{FEV}_{1}$ was observed up to 8 hours after inhalation of phosphatebuffered saline. However, in patient 1 , a $28 \%$ fall in $\mathrm{FEV}_{1}$ from baseline was observed 10 minutes after the challenge with 1:100 wt/vol extract. Two hours later, $\mathrm{FEV}_{1}$ returned to baseline values, with no late response. No significant new falls were observed in the peak respiratory flow recorded during the following 24 hours.

Likewise, patient 2 had a positive response in the bronchial provocation, this time with a 1:10 wt/vol extract. $\mathrm{FEV}_{1}$ decreased $43 \%$ after 5 minutes, and a late response was observed after 8 hours with a $26 \%$ fall in $\mathrm{FEV}_{1}$ (Figure). A spontaneous full recovery was made 12 hours after the

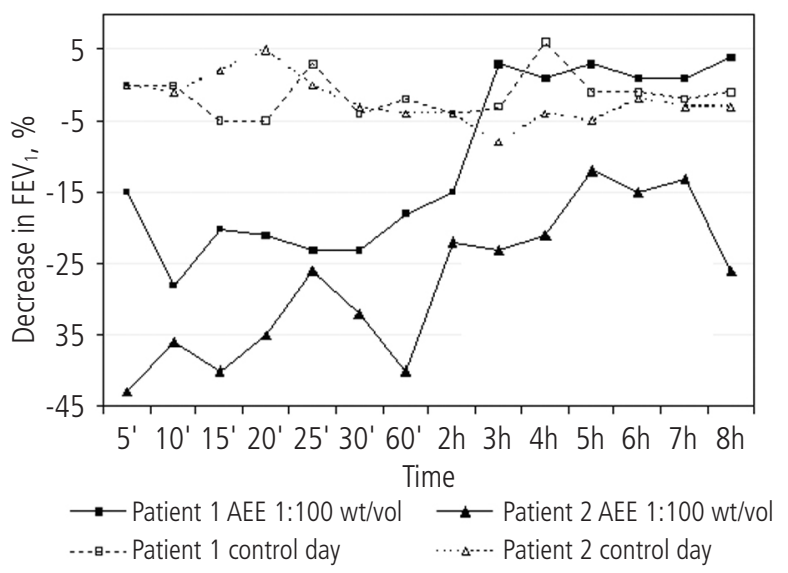

Figure. Specific inhalation challenge with Actinia equina extract (AEE). 
provocation. Additionally, we did not observe any significant new falls in the peak respiratory flow recorded during the following 24 hours.

Bronchial provocations were negative in 2 asthmatic patients used as controls at 1:10 wt/vol.

Fractional exhaled nitric oxide was measured in case 2 before and 24 hours after the specific provocation. There was a significant increase from $14 \mathrm{ppb}$ to $38 \mathrm{ppb}$.

Specific IgE for the extract was determined by immunoblotting [2]. Three IgE-binging bands were detected in each patient (patient 1, bands of 20,32, and $40 \mathrm{kDa}$; and patient 2 , bands of 25,30 , and $40 \mathrm{kDa}$ ).

No $A$ equina allergens have been identified in the www.allergen.org and www.allergome.org databases.

After diagnosis, the patients changed their working tasks to avoid exposure to the anemone.

Follow-up visits were made at 2, 4, and 8 months after diagnosis. The patients reported that they were now symptomfree with no need for regular asthma treatment.

Our review of the literature did not reveal any cases of this kind of occupational asthma. However, IgE-mediated anaphylaxis was reported in a diver who came into contact with A equina [4].

A equina is a common intertidal actinian anthozoan found on the rocky shores of the Atlantic throughout Western Europe and on the west coast of Africa [5]. It is commonly found on mussel shells and, as reported in our case study, can lead to serious allergic reactions in people working in the mussel industry. This industry is important in the northwest of Spain, where both patients worked.

It would be interesting to carry out an epidemiological study within the mussel industry to try to establish the prevalence of this kind of allergy.

We must also consider the possibility of an allergic reaction occurring when mussels bearing this anemone are handled by consumers, although no cases have been reported to date.

\section{Funding}

The authors declare that no funding was received for the present study.

\section{Conflicts of Interest}

The authors declare that they have no conflicts of interest.

\section{References}

1. Cohen SG, Zelaya-Quesada M. Portier, Richet, and the discovery of anaphylaxis: a centennial. J Allergy Clin Immunol. 2002;110:331-6.

2. Subiza JL, Caturla A, Pereira LF, Camargo MC, Bustos $A$, Boimorto $R$, et al. Evidence that a putative anti-idiotypic monoclonal antibody may actually be recognizing circulating immune complexes. J Autoimmun. 1992;5:363-77.

3. Subiza J, Subiza JL, Escribano PM, Hinojosa M, Garcia R, Jerez $M$, et al. Occupational asthma caused by ginseng dust. J Allergy Clin Immunol. 1991;88:731-6.
4. Gracia Bara MT, Iriarte P, Pineda F. Allergy to Actinia equina and Anemona viridis. Allergy. 2006;61:1151-2.

5. Davenport J, Moloney T, Kelly J. Common sea anemones Actinia equina are predominantly sessile intertidal scavengers. Marine Ecology Progress Series. 2011;430:147-55.

- Manuscript received August 29, 2017; accepted for publication April 9, 2018.

Javier Subiza

Centro de Asma y Alergia Subiza General Pardiñas, 116 28006 Madrid, Spain

E-mail: info@clinicasubiza.com 